\title{
PENGARUH JUMLAH MONOKLORO ASETAT TERHADAP KARAKTERISTIK KARBOKSIMETIL KITOSAN DARI KITOSAN CANGKANG DAN KAKI RAJUNGAN
}

\author{
Devi Ambarwaty Oktavia, Singgih Wibowo, dan Yusro Nuri Fawzya"?
}

\begin{abstract}
ABSTRAK
Riset ini bertujuan untuk mengetahui pengaruh jenis limbah rajungan (cangkang/punggung dan kaki) sebagai bahan baku kitosan dan rasio kitosan-monokloro asetat pada proses karboksimetilasi terhadap karakteristik karboksimetil kitosan yang dihasilkan. Perbandingan kitosan dan monokloro asetat yang digunakan adalah $1: 1 ; 0,9: 1,1$ dan $0,8: 1,2$. Hasil riset menunjukkan bahwa rendemen tertinggi $(93,8 \%)$ dan viskositas tertinggi (485 cPs) didapat dari perlakuan kitosan cangkang rajungan dengan perbandingan kitosan : monokloro asetat 0,9:1,1. Derajat substitusi tertinggi $(1,15)$ didapat dari perlakuan kitosan kaki rajungan dengan perbandingan kitosan : monokloro asetat $0,9: 1,1$. Sedangkan kelarutan tertinggi $(95,5 \%)$ didapat dari perlakuan kitosan cangkang rajungan dengan perbandingan kitosan: monokloro asetat $0,8: 1,2$. Adapun $\mathrm{pH}$ produk dari semua perlakuan berkisar antara $3,5-4$.
\end{abstract}

\section{ABSTRACT: Effect of amount of monochloro acetate on the characteristics of carboxy- methyl chitosan from carapace and leg swimcrab. By: Devi Ambarwaty Oktavia, Singgih Wibowo and Yusro Nuri Fawzya}

The purpose of this research was to study the effect of swimcrab waste type as a raw material of chitosan and mixing ratio of chitosan-monochloro acetate during carboxymethylation process on the characteristics of carboxymethyl chitosan produced. Ratio of chitosan : monochloro acetate used were $1: 1 ; 0.9: 1.1$ and 0.8:1.2. Chitosan made from carapace waste shell with the ratio of 0.9:1.1 to monochloro acetate produced higher yield (93.8\%) and higher viscosity (485 cPs) than the other treatments. The highest degree of substitution (i.e. 1.15) was resulted from leg waste shell chitosan with the ratio to monochloro acetate of 0.9:1.1, while higher solubility (i.e. $95.5 \%)$ was produced from carapace waste shell chitosan with the ratio to monochloro acetate of 0.8:1.2. The pH of carboxymethyl chitosan produced by all treatments were between 3.5 to 4 .

KEYWORDS: crab shell waste, mixing ratio of chitosan to monochloro acetate, carboxymethyl chitosan.

\section{PENDAHULUAN}

Kitin merupakan $\mathrm{N}$-asetilglukosamin yang banyak dijumpai di alam, terutama pada cangkang krustase. Apabila kitin mengalami deasetilasi baik secara kimia maupun enzimatis akan menghasilkan kitosan ( $\mathrm{Wu}$ \& Bough, 1978; Gates, 1991). Kitin, kitosan dan derivatnya merupakan biopolimer yang mempunyai potensi besar untuk dikembangkan di Indonesia mengingat kegunaannya yang luas mulai dari bidang kedokteran, industri pangan, farmasi, kosmetik, pertanian, dan lainnya. Hal tersebut dikarenakan kitosan dan derivatnya memiliki sifat-sifat istimewa dalam hal biokompatibilitas, biodegradasi, aktivitas biologis, tidak toksik, tidak menimbulkan alergi, dan kemampuannya dalam membentuk serat dan film (Wibowo et al., 2003).

Potensi bahan baku untuk kitin-kitosan di Indonesia, seperti limbah rajungan dan udang, cukup besar namun belum dimanfaatkan secara optimal. Produksi rajungan dan udang tahun 2002 masing-masing adalah 31.228 ton dan 241.485 ton (Direktorat Jenderal Perikanan Tangkap, 2004) menghasilkan limbah sekitar 135.000 ton. Pemanfaatannya sudah dilakukan tetapi baru sebagian kecil, yaitu sebagai komponen untuk pakan.

Jenis sumber asal kitin (bahan baku) menentukan karakteristik kitosan dan turunan yang dihasilkan. Struktur fisik dan kimia kitin/kitosan sangat bervariasi, antara lain tergantung pada posisi rantai $\mathrm{N}$ asetilglukosamin, derajat deasetilasi dan ikatan silang komponen struktural dengan komponen lain seperti protein dan glukan (Svitil et al., 1997). Selain faktor bahan baku, kualitas atau karakteristik karboksimetil kitosan juga ditentukan oleh proses produksinya.

Karboksimetil kitosan adalah turunan kitosan yang bersifat larut air, dibuat dengan mereaksikan kitosan

-) Peneliti pada Pusat Riset Pengolahan Produk dan Sosial Ekonomi Kelautan dan Perikanan 
dan monokloro asetat pada suasana basa (Muzzarelli et al., 1997). Karboksimetil kitosan dapat memperbaiki kitosan dalam hal kapabilitasnya secara fisik dan kimia, mempunyai viskositas yang tinggi dan kemampuan membentuk gel sehingga bisa digunakan dalam bidang pangan dan kosmetik (Chen et al., 2003: Anon., 2004).

Beberapa penelitian tentang karboksimetil kitosan yang sudah dilakukan antara lain adalah tentang proses karboksimetilasi menggunakan dimetilasetamid (DMAC) dan litium klorida ( $\mathrm{LiCl}$ ) untuk mengubah struktur kitosan (Sashiwa dalam Alamsyah, 2000), pengaruh derajat deasetilasi dan derajat substitusi karboksimetil kitosan terhadap sifat keterikatannya (Chen et al., 2004), pengaruh suhu eterifikasi terhadap karakteristik karboksimetil kitosan (Dwiyitno et al., 2004) dan penggunaan hidrogen alginat-karboksimetil kitosan untuk obat (Lin et al., 2005).

Pada penelitian ini dipelajari pengaruh jumlah monokloro asetat terhadap karakteristik karboksimetil kitosan yang dibuat dengan menggunakan kitosan dari sumber bahan baku berbeda, yaitu kitosan dari limbah cangkang dan kaki rajungan.

\section{BAHAN DAN METODE}

\section{Bahan Baku}

Bahan baku yang digunakan adalah limbah cangkang dan kaki rajungan (Portunus pelagicus) yang diambil dari pengolah rajungan di Cirebon. Limbah tersebut diangkut ke laboratorium Pusat Riset Pengolahan Produk dan Sosial Ekonomi Jakarta dengan di es. Sesampainya di laboratorium, limbah dipisahkan antara cangkang dan kaki. Selama sortasi limbah tetap dipertahankan dalam keadaan di es untuk menjaga kesegarannya.

\section{Metode}

Limbah rajungan yang telah dipisahkan diproses menjadi kitin dan dilanjutkan dengan perlakuan deasetilasi untuk menghasilkan kitosan. Kitosan yang diperoleh direaksikan dengan monokloro asetat untuk menghasilkan kitosan larut air.

\section{Pembuatan kitin dan kitosan dari limbah rajungan}

Pembuatan kitin dilakukan menurut metode Chen et al. (1997) yang dimodifikasi. Pertama-tama dilakukan perlakuan pendahuluan terhadap limbah cangkang dan kaki rajungan dengan cara merendam limbah rajungan dalam $2 \% \mathrm{NaOH}$ selama sekitar 12 jam, kemudian dicuci hingga $\mathrm{pH}$ netral dan dijemur sampai kering.

Terhadap limbah kering selanjutnya dilakukan deproteinasi menggunakan $\mathrm{NaOH}$ teknis $3,5 \%$ pada $70^{\circ} \mathrm{C}$ selama 2 jam, dan dicuci hingga $\mathrm{pH} 7$. Selanjutnya dilakukan demineralisasi dengan $\mathrm{HCl}$ teknis $15 \%$ pada suhu kamar selama 1 jam, dilanjutkan dengan pencucian hingga $\mathrm{pH} 7$ dan kemudian dijemur sampai kering sehingga diperoleh kitin.

Kitosan kasar diperoleh dengan menggunakan metode Dwiyitno et al. (2004) yang dimodifikasi. Deasetilasi kitin yang semula menggunakan $\mathrm{NaOH}$ teknis $60 \%$ selama 48 jam pada suhu $70^{\circ} \mathrm{C}$ (Dwiyitno et al., 2004) dimodifikasi menggunakan $\mathrm{NaOH}$ teknis $60 \%$ selama 72 jam suhu $70^{\circ} \mathrm{C}$. Selanjutnya dilakukan pencucian sampai $\mathrm{pH}$ netral dan dikeringkan di dalam oven $55-60^{\circ} \mathrm{C}$ selama 24 jam.

\section{Pembuatan kitosan larut air}

Proses produksi kitosan larut air (karboksimetil kitosan) dilakukan dengan menggunakan metode Bader \& Birkholz (1997) yang dimodifikasi sebagaimana yang digunakan Dwiyitno et al. (2004). Modifikasi yang dilakukan adalah dengan menggantikan larutan $\mathrm{NaOH}$ yang semula $50 \%$ menjadi $30 \%$ pada proses produksi karboksimetil kitosan, dan rasio kitosan : monokloro asetat yang bervariasi.

Kitosan kasar dilarutkan dalam asam asetat $1 \%$ kemudian ditambahkan $\mathrm{NaOH} 30 \%$ sehingga terbentuk endapan. Endapan dipisahkan dengan penyaringan kemudian ditambahkan monokloro asetat sesuai perlakuan, yaitu rasio kitosan : monokloro asetat masing-masing $0,8: 1,2 ; 0,9: 1,1$ dan $1: 1$. Proses eterifikasi (reflux) dilakukan pada suhu $70^{\circ} \mathrm{C}$ selama 2 jam. Setelah dingin dilakukan pengaturan $\mathrm{pH}$ hingga $\mathrm{pH}$ 4-5 menggunakan $\mathrm{NaOH} 10 \%$. Pengendapan dilakukan dengan menggunakan isopropil alkohol (IPA). Selanjutnya padatan dikeringkan dalam oven $55-60^{\circ} \mathrm{C}$ selama 24 jam. Diagram alir proses produksi karboksimetil kitosan disajikan pada Gambar 1.

\section{Pengamatan}

Terhadap produk yang dihasilkan (karboksimetil kitosan) dilakukan pengamatan terhadap rendemen, viskositas, kelarutan, $\mathrm{pH}$ dan derajat substitusi. Viskositas karboksimetil kitosan diukur dengan Brookfield viscometer (model LVF seri : 88883, menggunakan spindel no. 3 (Kyoon et al., 2003). Derajat substitusi diukur sesuai prosedur ASTM (Anon., 2002). Kelarutan ditentukan berdasarkan metode Lembono (1989) dengan cara melarutkan $1 \mathrm{~g}$ 


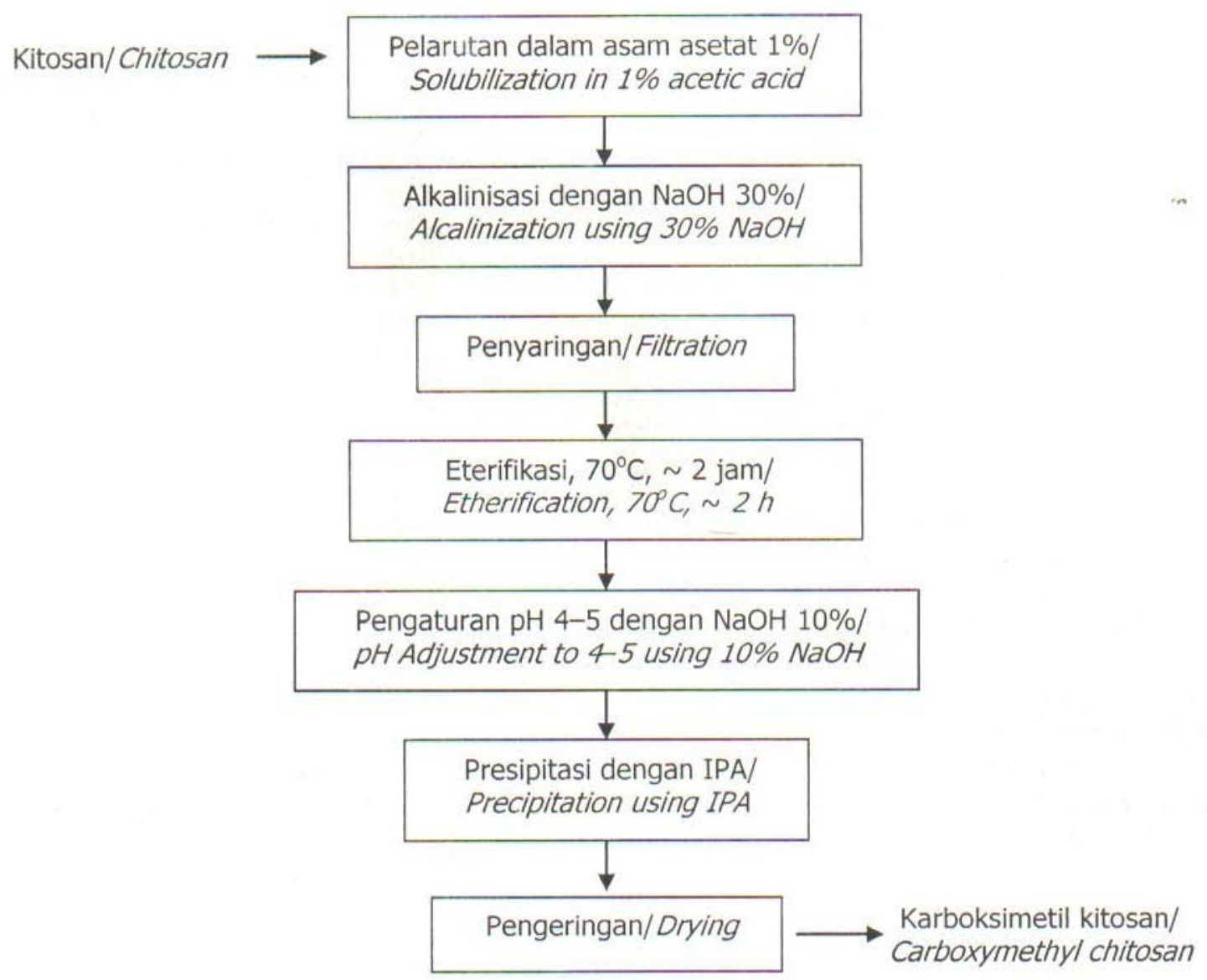

Gambar 1. Diagram alir produksi karboksimetil kitosan.

Figure 1. Flow chart of production of carboxymethyl chitosan.

karboksimetil kitosan dalam $100 \mathrm{~mL}$ akuades sehingga diperoleh konsentrasi 1\%. Kemudian dilakukan penyaringan menggunakan plankton net 200 mesh. Sisa karboksimetil kitosan yang tidak larut dikeringkan di oven $100^{\circ} \mathrm{C}$ selama 24 jam dan ditimbang. Bobot kering kemudian dibandingkan dengan bobot awal.

Rancangan percobaan yang dipakai adalah rancangan acak kelompok faktorial dengan dua kali ulangan. Terhadap data yang diperoleh dilakukan analisis sidik ragam (anova) dan apabila berbeda nyata dilakukan uji lanjut Duncan Multiple Range Test (DMRT) (Steel \& Torrie, 1989). Analisis data dilakukan menggunakan program SPSS versi 10.0 .

\section{HASIL DAN BAHASAN}

\section{Rendemen}

Salah satu karakteristik kitosan larut air yang diamati sebagai respon terhadap jenis bahan baku dan variasi rasio kitosan terhadap monokloro asetat adalah rendemen yang dihitung sebagai persentase karboksimetil kitosan terhadap bobot kitosan awal. Hasilnya menunjukkan bahwa rendemen produk berkisar antara 65,6\%-93,8\% (Gambar 2).

Pada Gambar 2 tampak bahwa terdapat kecenderungan meningkatnya rendemen yang dihasilkan dengan makin tingginya jumlah monokloro asetat yang ditambahkan. Kecenderungan peningkatan tersebut juga tampak akibat perbedaan jenis bahan yang digunakan. Meskipun demikian, kenaikan rendemen akibat makin tingginya monokloro asetat maupun akibat perbedaan jenis bahan yang digunakan secara statistik tidak nyata $(p>0,05)$.

Karboksimetil kitosan (KMK) yang dihasilkan dari kitosan cangkang rajungan dengan proses eterifikasi menggunakan rasio kitosan : monokloro asetat $0,9: 1,1$ menghasilkan rendemen tertinggi $(93,8 \%)$. Jika menggunakan kitosan dari kaki rajungan, diperlukan rasio 0,8:1,2 untuk menghasilkan rendemen tertinggi ( 90\%). Hasil ini tidak jauh berbeda dengan rendemen KMK yang dihasilkan dari kitosan limbah udang windu, yaitu 57-98\% (Dwiyitno et al., 2004). Dwiyitno et al. (2004) menggunakan rasio kitosan : monokloro asetat $1: 1$. 


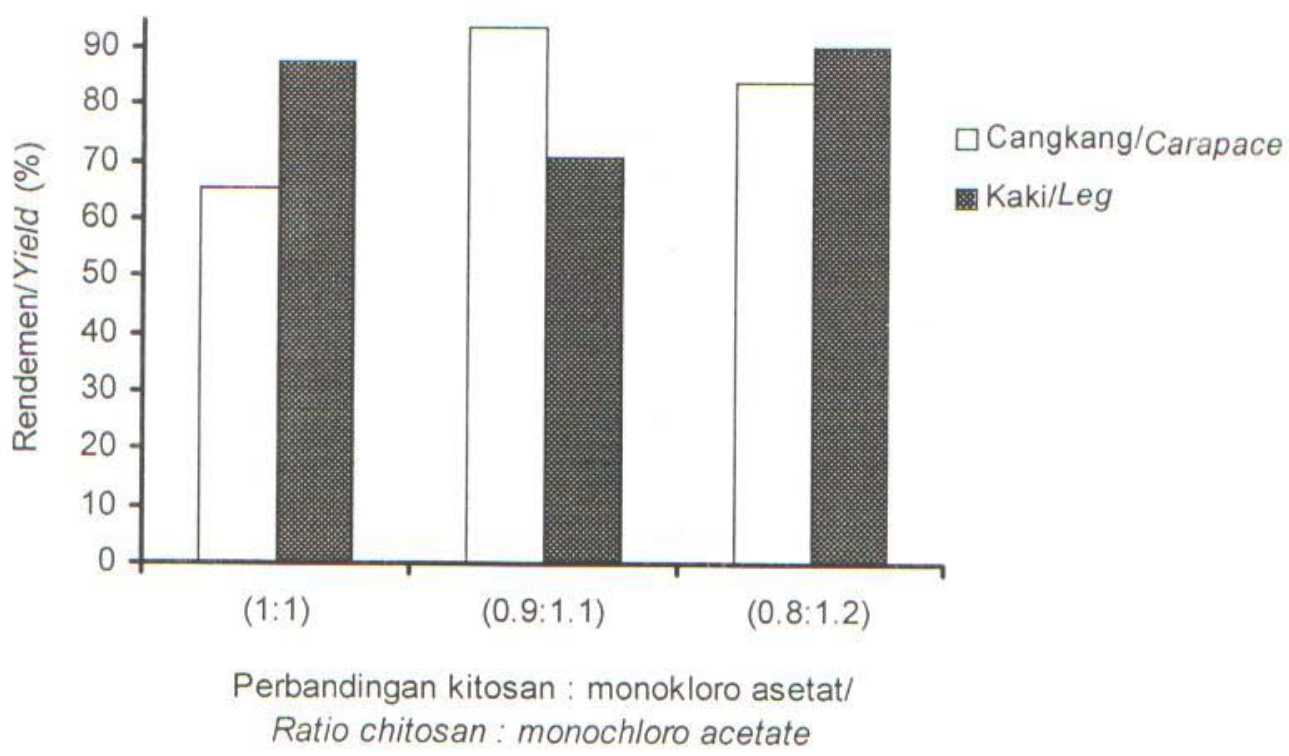
Gambar 2. Rendemen karboksimetil kitosan yang dibuat dari kitosan limbah cangkang dan kaki rajungan dengan berbagai rasio campuran kitosan dan monokloro asetat.
Figure 2. Yield of carboxymethyl chitosan made from swim crab carapace and leg chitosan at various mixing ratio of chitosan and monochloro acetate.

Meningkatnya rendemen disebabkan oleh banyaknya jumlah gugus asetil dari monokloro asetat yang mensubstitusi ion $\mathrm{H}^{+}$pada gugus $\mathrm{OH}$ dan amida kitosan. Bila jumlah monokloro asetat yang ditambahkan cukup banyak, rendemen karboksimetil kitosan juga akan meningkat. Selain rasio tersebut, suhu juga berperan terhadap meningkatnya rendemen dan penggunaan suhu yang tinggi akan mengakibatkan reaksi eterifikasi lebih baik (Bader \& Birkholz, 1997).

Hasil tersebut di atas memberikan indikasi bahwa peningkatan jumlah monokloro asetat yang digunakan dalam penelitian ini tidak berpengaruh secara nyata terhadap peningkatan rendemen. Di sisi lain, jenis bahan baku yang digunakan juga tidak berpengaruh secara nyata terhadap rendemen yang dihasilkan.

\section{Kelarutan}

Sifat karakteristik lain dari kitosan larut air adalah kelarutannya. Pengaruh jumlah monokloro asetat dan jenis bahan baku yang digunakan terhadap kelarutan KMK yang dihasilkan tampak seperti pada Gambar 3. Hasilnya cukup bervariasi, yaitu berkisar antara $64,5 \%-95,5 \%$.

Jumlah monokloro asetat memberikan pengaruh yang nyata $(p<0,05)$ terhadap kelarutan KMK. Peningkatan jumlah monokloro asetat hingga 1,1 bagian (rasio kitosan : monokloro asetat $=0,9: 1,1$ ) mampu meningkatkan kelarutan KMK secara nyata $(p<0,05)$. Peningkatan jumlah monokloro asetat lebih dari itu (rasio kitosan : monokloro asetat $=0,9: 1,1$ dan $0,8: 1,2)$ tidak mampu meningkatkan kelarutan KMK secara nyata $(p<0,05)$.

Pada dasarnya, eterifikasi dengan monokloro asetat merupakan upaya untuk meningkatkan jumiah gugus fungsional yang lebih bersifat polar sehingga meningkatkan kelarutan. Semakin banyak jumlah monokloro asetat yang digunakan pada reaksi eterifikasi akan mengakibatkan makin banyak gugus asetil yang mensubstitusi ion $\mathrm{H}^{+}$, sehingga menghasilkan kelarutan KMK yang tinggi pula. Namun demikian, hasil penelitian ini menunjukkan bahwa peningkatan jumlah monokloro asetat hingga batas tertentu saja (rasio kitosan : monokloro asetat = $0,9: 1,1$ ) yang mampu meningkatkan kelarutan KMK secara nyata. Peningkatan jumlah monokloro asetat yang lebih tinggi tidak memberikan pengaruh cukup berarti terhadap peningkatan kelarutan KMK. Fenomena ini mungkin dapat dijelaskan dengan melihat tingkat substitusinya (derajat substitusi).

Di sisi lain, dari gambar tersebut juga tampak bahwa KMK yang dihasilkan dari kitosan kaki rajungan memiliki kelarutan lebih rendah $(79,9 \%)$ daripada KMK dari kitosan cangkang $(95,5 \%)$. Jenis bahan baku berpengaruh nyata terhadap kelarutan KMK yang dihasilkan $(p<0,05)$. Mengingat perbedaan kelarutan yang cukup besar tersebut, pemisahan kaki dengan 


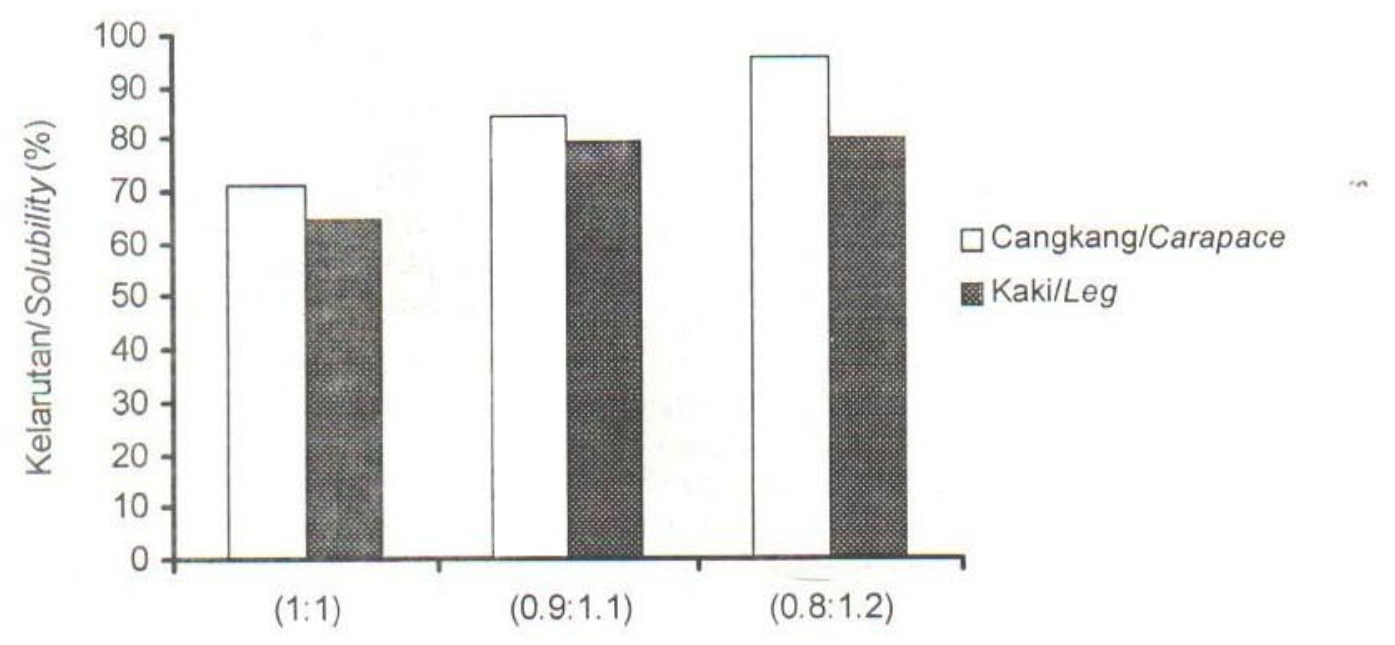

Rasio kitosan : monokloro asetat/

Chitosan : monochloro acetate ratio

Gambar 3. Kelarutan karboksimetil kitosan yang dibuat dari kitosan limbah cangkang dan kaki rajungan dengan berbagai rasio campuran kitosan dan monokloro asetat.

Figure 3. Solubility of carboxymethyl chitosan made from swim crab carapace and leg chitosan at various mixing ratio chitosan and monochloro acetate.

cangkang rajungan diharapkan akan dapat menghasilkan produk KMK yang lebih homogen dengan kelarutan yang lebih baik.

Cangkang rajungan menghasilkan KMK yang lebih tinggi kelarutannya daripada kaki rajungan. Perbedaan fungsi bagian tubuh rajungan (cangkang dan kaki) mungkin dapat menyebabkan perbedaan keberadaan kitosan pada bahan tersebut sehingga menuntut perlakuan yang tidak sama. Kemungkinan lain adalah adanya perbedaan fisik bahan antara cangkang dan kaki. Hal ini mengindikasikan perlunya perlakuan yang lebih pada kaki rajungan untuk menghasilkan KMK yang setara dengan KMK dari cangkang rajungan. Cangkang rajungan yang berupa lembaran terbuka memberikan peluang lebih besar bagi akses reaksi selama proses pembuatan kitosan, baik dengan $\mathrm{NaOH}$ pada tahap deproteinasi maupun $\mathrm{HCl}$ pada tahap demineralisasi, daripada kaki rajungan yang menyerupai pipa.

Kelarutan suatu zat pada dasarnya tergantung pada sifat fisikokimia zat terlarut dan pelarutnya, suhu, tekanan, dan pH larutan (Fawzya et al., 2004). Demikian juga dengan kelarutan KMK, sangat ditentukan oleh keberhasilan reaksi eterifikasi dengan monokloro asetat. Semakin banyak gugus asetil yang mensubstitusi ion $\mathrm{H}^{+}$pada gugus hidroksil maupun amina, maka kelarutan KMK semakin tinggi (Dwiyitno et al., 2004). Adanya peningkatan kelarutan KMK sesuai dengan bertambahnya perbandingan jumlah monokloro asetat yang ditambahkan pada kitosan. Aumeilia (2004) juga mendapatkan bahwa penggunaan jumlah mol monokloro asetat yang lebih tinggi akan meningkatkan nilai kelarutan karboksimetil kitin. Namun data kelarutan ini tidak menunjukkan korelasi dengan derajat substitusi (DS) (Gambar 5). Perlakuan rasio $0,8: 1,2$ yang menghasilkan kelarutan tertinggi tidak menghasilkan DS yang tertinggi. DS tertinggi dihasilkan oleh perlakuan rasio $0,9: 1,1$. Perlakuan rasio 1:1 menghasilkan kelarutan yang tidak terlalu tinggi (sekitar 64\%), meskipun DS mencapai nilai sekitar 1. Hal yang sama dilaporkan oleh Nudga et al. (1974) dalam Hayes (1986), bahwa O-Karboksimetil kitosan yang dihasilkan belum larut dalam air meskipun mempunyai DS $>1$, dan tidak larut jika DS $<1$. Sebaliknya, Muzzarelli et al. (1982) dalam Hayes (1986) melaporkan bahwa N-Karboksimetil kitosan larut dalam air meskipun DS-nya berkisar antara 0,251,0. Sedangkan Hayes (1986) menemukan bahwa N,O-Karboksimetil kitosan dengan DS 0,4-0,8 bersifat larut dalam air.

\section{Viskositas}

Karakteristik lain yang mencirikan suatu polimer adalah kemampuannya dalam menghasilkan larutan yang lebih kental daripada pelarut murninya. Pengaruh rasio kitosan : monokloro asetat dan jenis bahan baku 
yang tidak-berbeda nyata terhadap viskositas KMK yang dihasilkan, disajikan pada Gambar 4 yang hasilnya bervariasi antara $450-485 \mathrm{cPs}$.

Viskositas larutan polimer cenderung berkurang dengan turunnya konsentrasi (Fawzya et al., 2004). Selain itu, viskositas kitosan dan turunannya berkaitan dengan panjang rantai polimer yang juga mencerminkan berat molekulnya. Polimer dengan rantai panjang sehingga $\mathrm{BM}$-nya tinggi akan memiliki viskositas tinggi dan sebaliknya (Kyoon et al., 2003). Beberapa faktor yang dapat menyebabkan terjadinya pemotongan rantai polimer sehingga menyebabkan turunnya viskositas adalah suhu, waktu, enzim-enzim tertentu dan basa kuat misalnya pada proses deasetilasi kitin dan karboksimetilasi (Rinaudo et al., 1992). Pemanasan akan memutus rantai polimer (depolimerisasi) yang akan menghasilkan KMK dengan rantai yang lebih pendek. Semakin pendek

\section{Derajat Substitusi (DS)}

Derajat substitusi (DS) menggambarkan jumlah gugus hidroksil pada monomer $\mathrm{N}$-asetil-glukosamin yang disubstitusi oleh gugus karboksimetil. Derajat substitusi pada KMK yang dihasilkan dari kitosan cangkang rajungan berkisar antara 1,05-1,11, sedangkan yang diperoleh dari kitosan kaki rajungan berkisar antara 1,00-1,15 (Gambar 5).

Terlihat pada Gambar 5 bahwa peningkatan jumlah monokloro asetat tidak selalu menghasilkan DS yang tinggi. Nilai DS 1-2 menunjukkan bahwa substitusi kemungkinan terjadi di dua tempat yaitu di gugus amin $\left(\mathrm{NH}_{2}\right)$, dan gugus hidroksil $(\mathrm{OH})$ pada posisi $\mathrm{O}$ di $\mathrm{C}_{6}$. Menurut Hayes (1986), setiap monomer kitosan secara teoritis dapat mengalami substitusi di tiga tempat yaitu pada posisi $\mathrm{N}$ dan gugus hidroksil pada posisi $\mathrm{O}$ di $\mathrm{C}_{3}$ dan $\mathrm{O}$ di $\mathrm{C}_{6}$; namun karena posisi $\mathrm{N}$

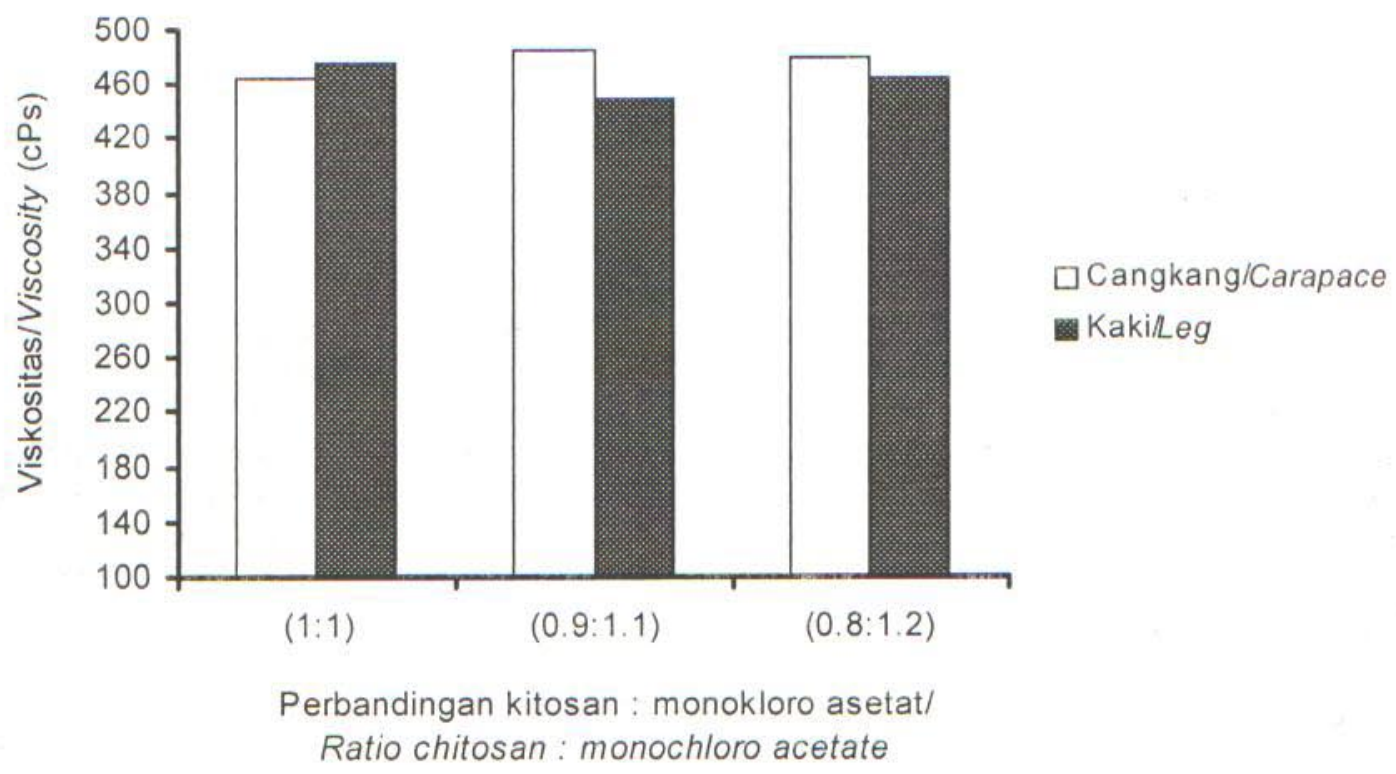

Gambar 4. Viskositas karboksimetil kitosan yang dibuat dari kitosan limbah cangkang dan kaki rajungan dengan berbagai rasio campuran kitosan dan monokloro asetat.

Figure 4. Viscosity of carboxymethyl chitosan made from swim crab carapace and leg chitosan at various mixing ratio chitosan and monochloro acetate.

jumlah polimer menyebabkan berat molekul semakin rendah, sementara viskositas berkaitan dengan berat molekul sehingga viskositas juga rendah (Dwiyitno et al., 2004). Deasetilasi dengan $\mathrm{NaOH} 60 \%$ dapat menyebabkan depolimerisasi kitosan yang akan digunakan sebagai bahan baku pembuatan KMK. Hasil penelitian Bough et al. (1978) menunjukkan bahwa deasetilasi dengan $\mathrm{NaOH} 35-50 \%$ dapat menurunkan viskositas dan berat molekul kitosan. dan posisi $\mathrm{O} \mathrm{di} \mathrm{C}_{6}$ jauh lebih reaktif daripada $\mathrm{O} \mathrm{di}_{3}$ maka substitusi kemungkinan besar hanya terjadi di posisi $\mathrm{N}$ dan posisi $\mathrm{O}$ di $\mathrm{C}_{6}$, sehingga nilai $\mathrm{DS}$ maksimum adalah 2. Penelitian Hayes (1986) diperkuat juga oleh Thatte (2004) yang menunjukkan bahwa reaksi eterifikasi yang terjadi pada kitosan menjadi KMK adalah seperti pada Gambar 6 dan 7.

Derajat substitusi yang dihasilkan dengan rasio kitosan : monokloro asetat $0,9: 1,1$ berbeda nyata 


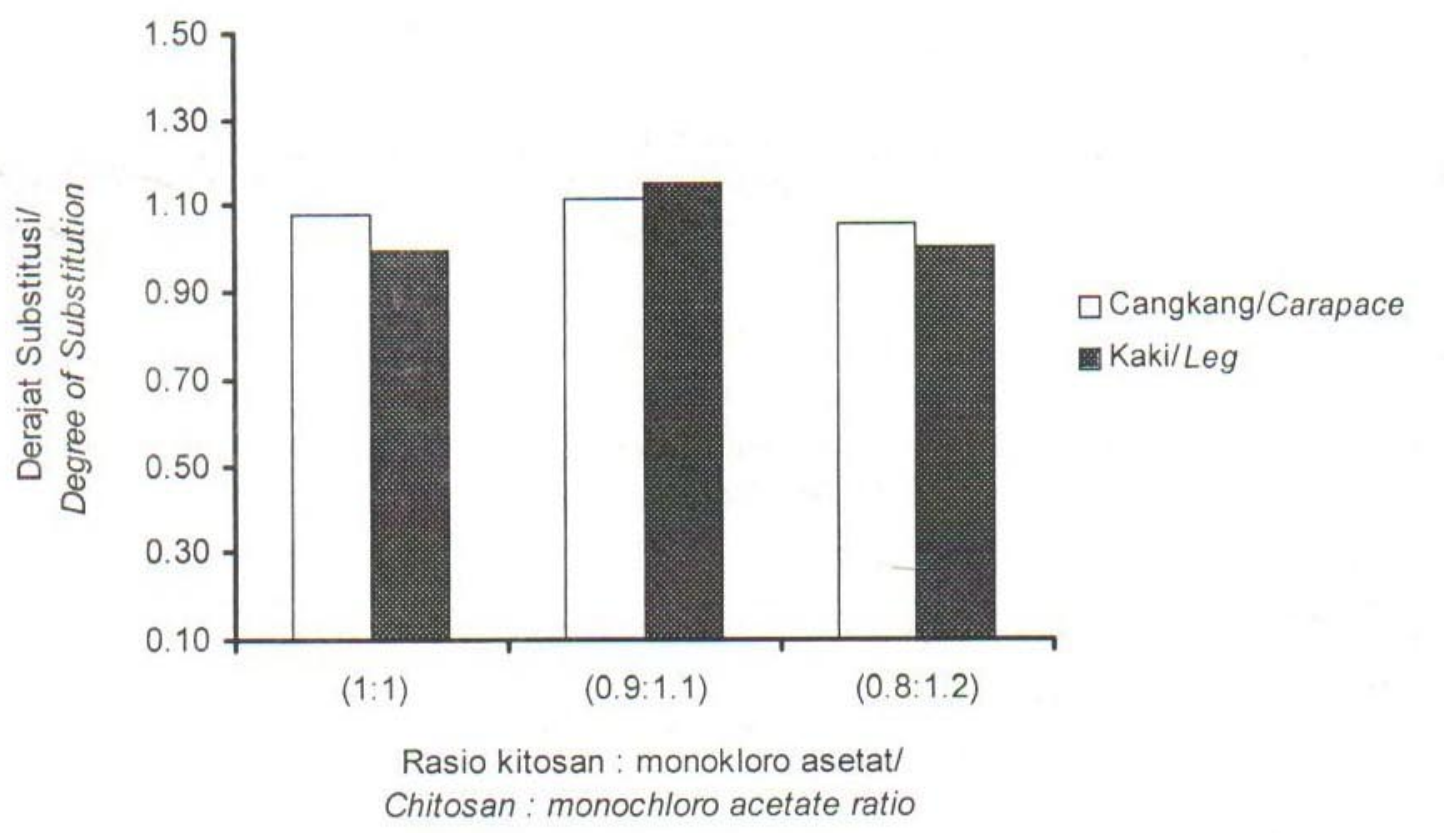

Gambar 5. Derajat substitusi karboksimetil kitosan yang dibuat dari kitosan limbah cangkang dan kaki rajungan dengan berbagai rasio campuran kitosan dan monokloro asetat.

Figure 5. Degree of substitution of carboxymethyl chitosan made from swim crab carapace and leg chitosan at various mixing ratio chitosan and monochloro acetate.

$(p<0,05)$ dengan rasio kitosan:monokloro asetat $0,8: 1,2$. Rasio kitosan:monokloro asetat $0,9: 1,1$ dan $0,8: 1,2$ tidak berbeda nyata $(p>0,05)$ terhadap rasio kitosan : monokloro asetat 1:1. Perlakuan jenis limbah cangkang tidak berbeda nyata dengan jenis limbah kaki.

Hasil ini tampaknya sejalan dengan kelarutan KMK yang dihasilkan. Peningkatan jumlah monokloro asetat hingga rasio kitosan : monokloro asetat 0,9:1,1 dapat meningkatkan DS secara nyata, lebih dari itu pengaruhnya tidak cukup berarti. Ini memberikan indikasi bahwa peningkatan kelarutan KMK yang dihasilkan berkaitan erat dengan tingkat DSnya. Tampaknya efektifitas substitusi ditentukan oleh jumlah monokloro asetat yang ditambahkan. Penambahan monokloro asetat yang berlebihan tidak

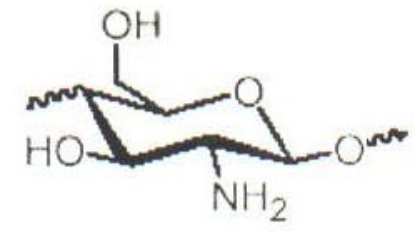

Chitosan
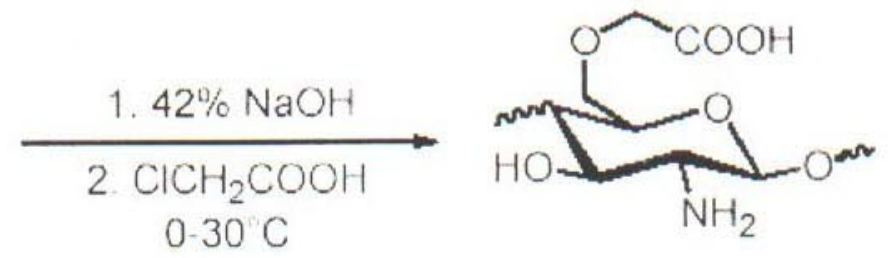

O-carboxymethyl chitosan

Gambar 6. Karboksimetilasi kitosan pada posisi O.

Figure 6. 0-Carboxymethylation of chitosan. 


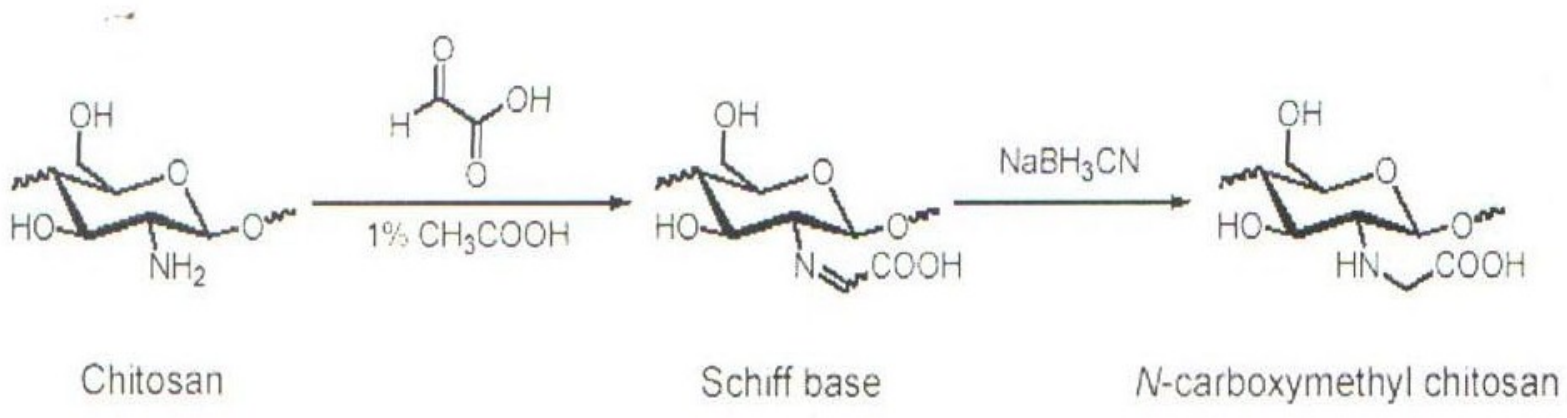

Gambar 7. Karboksimetilasi kitosan pada posisi N.

Figure 7. $\mathrm{N}$-Carboxymethylation of chitosan.

Sumber/Source: Hayes (1986); Thatte (2004)

memberikan pengaruh yang lebih baik, baik terhadap DS maupun kelarutan KMK yang dihasilkan. Bagaimana hal ini dapat terjadi perlu dikaji lebih lanjut. Kemungkinan terjadinya polimerisasi atau reaksi silang tampaknya dapat dikesampingkan mengingat rendemen yang dihasilkan tidak berbeda nyata. Faktor waktu mungkin dapat meningkatkan DS maupun kelarutan KMK karena akan memberikan peluang lebih banyak bagi terjadinya reaksi eterifikasi.

Hal ini kemungkinan disebabkan oleh volume yang ada di dalam sistem, penambahan monokloro asetat yang semakin banyak sehingga volume di dalam sistem juga semakin banyak mengakibatkan substitusi belum berjalan optimal dengan waktu reaksi yang sama (2 jam). Akibatnya nilai DS belum meningkat. Ada kemungkinan apabila waktu eterifikasi diperpanjang akan menghasilkan nilai DS yang meningkat. Substitusi terjadi pada posisi $\mathrm{N}$ dan masing-masing dari 2 gugus hidroksil pada posisi $O$ kitosan (posisi $\mathrm{O}$ di $\mathrm{C}_{3}$ dan $\mathrm{O}$ di $\mathrm{C}_{6}$ ), tetapi hanya di gugus $-\mathrm{NH}_{2}$ dan $-\mathrm{OH}$ pada posisi $\mathrm{C}_{6}$ yang secara nyata terjadi substitusi.

Derajat substitusi juga dipengaruhi oleh jumlah natrium hidroksida yang digunakan pada saat pembentukan alkoksida kitosan. Menurut Manguiat et al. (2001) dalam Fawzya et al. (2004) adanya variasi nilai derajat substitusi kemungkinan disebabkan terbentuknya reaksi samping, yaitu asam glikolat yang menyebabkan asam monokloro asetat tidak tersubstitusi secara sempurna karena sebagian telah bereaksi dengan natrium hidroksida.

\section{$\mathrm{pH}$}

Nilai $\mathrm{pH}$ berpengaruh pada kualitas $\mathrm{KMK}$, karena pemanfaatannya akan semakin luas dengan $\mathrm{pH}$ yang mendekati netral (Wuriyandari, 2002). Derajat keasaman produk KMK yang didapat berkisar antara 3,5-4 (Tabel 1).

Nilai $\mathrm{pH}$ yang didapat masih di bawah netral, sebagaimana hasil yang diperoleh oleh Dwiyitno (2003) yaitu $\mathrm{pH} \leq 4$. Nilai $\mathrm{pH}$ ini sesuai dengan perlakuan pengaturan $\mathrm{pH}$ yaitu setelah reaksi eterifikasi, $\mathrm{pH}$ yang didapatkan masih belum mendekati $\mathrm{pH}$ netral, karena pada penelitian ini tidak dilakukan pencucian terhadap produk KMK yang dihasilkan. Tidak ada perbedaan nyata antar perlakuan dan jenis limbah rajungan yang digunakan. Untuk menghasilkan $\mathrm{KMK}$ dengan $\mathrm{pH}$ netral, dapat dilakukan

Tabel 1. pH karboksimetil kitosan

Table 1. pH of carboxymethyl chitosan

\begin{tabular}{lccc}
\hline \multirow{2}{*}{ Jenis limbah/Type of waste } & \multicolumn{2}{c}{$\begin{array}{c}\text { Perbandingan kitosan : monokloro asetat/ } \\
\text { Ratio chitosan }: \text { monochloro acetate }\end{array}$} \\
\cline { 2 - 3 } & \multicolumn{1}{c}{$\mathbf{1 : 1}$} & $\mathbf{0 . 9}: \mathbf{1 . 1}$ & $\mathbf{0 . 8 : 1 . 2}$ \\
\hline Cangkang/Carapace & $3.5 \pm 0.71$ & $3.5 \pm 0.71$ & $4.0 \pm 0$ \\
Kaki/Leg & $3.5 \pm 0.71$ & $3.5 \pm 0.71$ & $4.0 \pm 0$ \\
\hline
\end{tabular}


dengan cara pencucian berulang-ulang menggunakan metanol yang harganya relatif lebih murah dibandingkan isopropil alkohol (IPA)

\section{KESIMPULAN}

1. Jumlah monokloro asetat yang digunakan maupun jenis bahan baku tidak berpengaruh nyata terhadap rendemen KMK yang dihasilkan. Rendemen KMK tertinggi adalah 93,8\% yang diperoleh dari kitosan cangkang rajungan yang mendapat perlakuan eterifikasi dengan rasio kitosan : monokloro asetat 0,9:1,1.

2. Jumlah monokloro asetat maupun jenis bahan berpengaruh nyata terhadap kelarutan KMK yang dihasilkan. Monokloro asetat berpengaruh nyata terhadap KMK yang dihasilkan hingga rasio kitosan : monokloro asetat 0,9:1,1 dan lebih dari itu tidak memberikan pengaruh berarti. Kelarutan tertinggi adalah $95,5 \%$ yang diperoleh dari kitosan cangkang rajungan dengan perlakuan eterifikasi menggunakan rasio kitosan : monokloro asetat 0,8:1,2. Sementara itu, kitosan cangkang rajungan menghasilkan KMK dengan kelarutan lebih tinggi daripada KMK dari kitosan kaki rajungan.

3. Jumlah monokloro asetat berpengaruh nyata terhadap derajat substitusi KMK yang dihasilkan hingga pada rasio kitosan : monokloro asetat $0,9: 1,1$, namun selebihnya tidak berpengaruh. Sementara itu, jenis bahan tidak memberikan pengaruh nyata terhadap viskositas maupun derajat substitusi KMK yang dihasilkan.

4. Proses untuk menghasilkan KMK yang digunakan dalam penelitian ini masih belum mampu menghasilkan KMK dengan $\mathrm{pH}$ netral atau mendekati netral.

5. Penambahan monokloro asetat sebaiknya dibatasi hingga rasio kitosan : monokloro asetat 0,9:1,1 untuk menghasilkan tingkat kelarutan dan derajat substitusi yang optimal.

\section{SARAN}

1. Untuk menghasilkan produk KMK dengan kelarutan homogen dan lebih baik, hendaknya dilakukan pemisahan antara kaki dan cangkang rajungan.

2. Perlu dilakukan upaya perbaikan proses yang digunakan untuk menghasilkan KMK dengan $\mathrm{pH}$ yang netral atau mendekati netral.

3. Faktor waktu dan suhu perlu dipertimbangkan sebagai variabel yang dapat berpengaruh terhadap DS maupun kelarutan KMK.
4. Pengaruh jumlah monokloro asetat yang berlebihan perlu dikaji untuk dapat menjelaskan fenomena yang ada.

\section{DAFTAR PUSTAKA}

Anonymous. 2002. American Society for Testing Materials (ASTM) Method. 6(3): 314-316.

Anonymous. 2004. There is A Lot More to Shell Fish than Meets The Eye. www.cheminst.ca/ncw/articles/ 1995_shellfish_e_.htmlinst.ca/ncw/article.

Alamsyah, A. 2000. Modifikasi Pembuatan Kitosan Larut Air. Skripsi. Program Studi Teknologi Hasil Perikanan. Fakultas Perikanan. IPB. Bogor. 36 pp.

Aumeilia, W. 2004. Pengaruh Jumlah Asam Monokloro Asetat dan Jenis Pelarut Organik Pengendap pada Pembentukan Karboksimetil Kitin. Skripsi. Fakultas Farmasi. Universitas Pancasila. Jakarta. p. 38-40

Bader, H.J. and Birkholz, E. 1997. Teaching chitin chemistry. In Muzzarelli, R.A.A and Peter, M.G. (eds.). Chitin Handbook. European Chitin Society. p. 507-519.

Bough, W.A., Wu, A.C.M., Campbell, T.E., Holmes, M.S., and Perkin, B.E. 1978. Influence of manufacturing variables of the characteristics and effectiveness of chitosan products. Biotechnology Bioengineering. 20: $1945-1955$.

Chen, Rong-Huei, Jaan-Rong Chang, and Ju-Shii Shyur. 1997. Effects on ultrasonic conditions and storage in acidic solutions on changes in molecular weight and polydispersity of treated chitosan. Carbohydrate Research. 299: 287-294.

Chen, Lingyun, Yumin Du, and Xiaoqing Zeng. 2003. Relationships between the molecular structure and moisture-absorpstion and moisture-retention abilities of carboxymethyl chitosan. II. Effect of degree of deacetylation and carboxymethylation. Carbohydrate Research. 338: 333-340.

Chen, Lingyun, Zhigang Tian, Yumin Du, and Sun, L. 2004. Effect of the degree of deacetylation and the substitution of carboxymethyl chitosan on its aggregation behavior. J. Polymer Science Part B: Polymer Physics. 43(3): 296-305.

Direktorat Jenderal Perikanan Tangkap. 2004. Statistik Perikanan Tangkap Indonesia. Departemen Kelautan dan Perikanan. Direktorat Jenderal Perikanan Tangkap. Jakarta. 17 pp.

Dwiyitno. 2003. Pengaruh Suhu terhadap Karakteristik Karboksimetil Kitosan (CMCTs). Laporan Teknis. Bagian Proyek Riset Pengolahan Produk dan Sosial Ekonomi Kelautan dan Perikanan. Jakarta. p. 4-6.

Dwiyitno, Basmal, J., dan Mulyasari. 2004. Pengaruh suhu esterifikasi terhadap karakteristik karboksimetil kitosan (CMCts). J. Penel. Perik. Indonesia. Edisi Pasca Panen. 10(3): 67-73.

Fawzya, Y.N., Zilda, D.S., Mulyasari, Chasanah, E., Ambarwaty, D., Wibowo, S., dan Suparno. 2004. Pengaruh suhu dan perbandingan kitosan dengan asam monokloro asetat (kimo) terhadap karakteristik 
karbokšimetil kitosan. Laporan Teknis Riset Produksi Kitosan dan Derivatnya serta Uji Aplikasinya. Bagian Proyek Riset Pengolahan Produk dan Sosial Ekonomi Kelautan dan Perikanan. Jakarta. p. 39-70.

Gates, K.W. 1991. Waste reduction, water conservation and recovery of seafood by products. Marine Technol Soc. J. 25: 44-51.

Hayes, E.R. 1986. N, O-Carboxymethyl Chitosan and Preparative Method Therefore. US Patents. 4, 619, 995. $7 \mathrm{pp}$

Kyoon, N.H., Won, J.N., and Meyers, S.P. 2003. Effect of time/temperature treatment parameters on depolymerization of chitosan. J. Appl. Poly. Sci. 87: 18901894.

Lembono, S. 1989. Pembuatan Susu Bubuk Kedelai dengan Alat Pengering Semprot. Skripsi. Fakultas Teknologi Pertanian. IPB. Bogor. 39 pp.

Lin, Yu-Hsin, Hsiang-Fa Liang, Ching-Kuang Chung, MeiChin Chen, and Hsing-Wen Sung. 2005. Physically crosslinked alginate/n,o-carboxymethyl chitosan hydrogels with calcium for oral delivery of protein drugs. Biomaterials. 26: 2105-2113.

Muzzarelli, R.A.A., Rocchetti, R., Stanic, V., and Weckx, M. 1997. Methods for the determination of degree of acetylation of chitin and chitosan. In Muzzarelli, R.A.A. and Peter, M.G. (eds.). Chitin Handbook. European Chitin Society. p. 109-132.

Rinaudo, M., Pham Le Dung, and Milas, M.1992. A new and simple method of synthesis of carboxymethylchitosans. In Brine, C.J., Sandford, P.A. and Zikakis,
J.P. (eds.). Advances in Chitin and Chitosan. Elsevier Appl. Sci. p. 516-523.

Steel, R.G.D. and Torrie, J.H. 1989. Prinsip dan Prosedur Statistika. $2^{\text {nd }}$ ed. PT. Gramedia, Jakarta. 748 pp.

Svitil, A.L., Nichadain, S.N., Moore, J.A. and Kirchman, D.L. 1997. Chitin degradation proteins produced by the marine bacterium Vibrio harveyii growing on different forms of chitin. Appl. Environ. Microbiol. 63(2): 408-413.

Thatte, M.R. 2004. Synthesis and Antibacterial Assessment of Water-Soluble Hydrophobic Chitosan Derivatives Bearing Quaternary Ammonium Functionality. Dissertation. Faculty of Louisiana State University and Agricultural Mechanical College. Department of Chemistry. Baton Rouge - Los Angeles. 107 pp.

Wibowo, S., Savant, V. and Torres, J.A. 2003. Effect of Chitosan Concentration and Treatment Time on Protein Adsorption From Surimi Wash Water. [PhD dissertation], Corvallis, OR: Oregon State Univ. 142 pp.

Wu, A.C.M. and Bough, W.A. 1978. A study of variables in the chitosan manufacturing process in relation to molecular weight distribution, chemical characteristics and waste-treatment effectiveness. In Muzarelli, R.A.A. and Pariser, E.R. (eds.). Proceedings of The First International Conference on Chitin/Chitosan. Cambridge, MA. p. 88-102.

Wuriyandari, Y. 2002. Pengembangan Turunan Kitosan Larut Air. Skripsi. Fakultas Matematika dan IImu Pengetahuan Alam. Universitas Negeri Jakarta. 16 pp. 